\title{
KEBIJAKAN PENGAWASAN TERHADAP PRODUK UMKM SEBAGAI UPAYA PERLINDUNGAN PADA KONSUMEN
}

\author{
Siti Mariyam *
}

\begin{abstract}
In the market there are many outstanding goods and / or services produced by UMKM. UMKM is indeed a growing business sector in the community that proved able to compete with other business actors. Through the economic policy package of President Joko Widodo, the government encourages the empowerment of UMKM. Although the government encourages the progress and development of UMKM but the circulation of UMKM products should be supervised. This is because there are still many products of UMKM, especially food circulating in the market that has not met the quality standards and labeling, especially labels expired so that this can endanger consumers. Therefore it is necessary to supervise the products of UMKM as an effort to protect the consumer. Supervision includes quality standards, labeling, standard clauses, and advertising. Such supervision is important to protect consumers from loss of goods that do not meet the standards specified in the legislation.
\end{abstract}

Keywords: Supervision, UMKM Products, Consumer Protection.

\section{PENDAHULUAN}

Terlepas dari berbagai kelemahan yang ada, pembangunan ekonomi Indonesia selama beberapa dekade belakangan ini telah menghasilkan banyak kemajuan. Kemajuan tersebut didorong oleh kebijakan pembangunan diberbagai bidang, di antaranya kebijakan pembangunan di bidang ekonomi. Namun demikian, meskipun telah banyak kemajuan yang dicapai, antara lain ditunjukkan dengan pertumbuhan ekonomi, masih banyak pula tantangan atau persoalan dalam pembangunan ekonomi yang belum terpecahkan, seiring dengan adanya kecenderungan lobalisasi perekonomian serta dinamika dan perkembangan usaha swasta.

* Siti Mariyam, Dosen fakultas hukum UNTAG Semarang dapat dihubungi melalui emailmariyamst_66@yahoo.co.id
Peluang-peluang usaha yang tercipta selama ini kenyataannya belum membuat seluruh masyarakat mampu dan dapat berpartisipasi dalam pembangunan di berbagai sektor ekonomi. Perkembangan usaha swasta selama periode tersebut, di satu sisi diwarnai oleh berbagai bentuk kebijakan pemerintah yang kurag tepat sehingga pasar menjadi terdistorsi. Di sisi lain perkembangan usaha swasta dalam kenyataannya sebagian besar merupakan perwujudan persaingan usaha yang tidak sehat. ${ }^{1}$

Pemerintah perlu mencegah persaingan usaha yang tidak sehat yang dilakukan oleh para pelaku usaha. Pencegahan yang dilakukan pemerintah dengan membuat kebijakan pengawasan terhadap barang dan / atau jasa yang beredar. Hal ini dimaksudkan untuk

1 H.R Daeng Naja, 2009, Pengantar Hukum Bisnis Indonesia, Penerbit Pustaka Yustisia, Yogyakarta, hlm. 157. 
melindungi konsumen dari perbuatan curang pelaku usaha.

Kebijakan pengawasan terhadap produk UMKM dibuat oleh pemerintah sebagai wujud dari konsep negara kesejahteraan. Adapun tujuan negara tertuang dalam Pasal IV Pembukaan Undang-Undang Dasar tahun 1945 (UUD 1945). Tujuan negara tersebut dituangkan dalam Pasal 33 UUD 1945 sebagai landasan kebijakan perundang-undangan di bidang ekonomi. Salah satu kebijakan ekonomi presiden Jokowi adalah kebijakan di bidang pemberdayaan UMKM.

Pengawasan terhadap barang dan/jasa hasil produksi UMKM perlu dilakukan mengingat jenis bisnis ini banyak sekali. Bisnis UMKM sudah terbukti lebih tahan terhadap krisis ekonomi dan didorong oleh pemerintah untuk dapat bersaing di pasar internasional. Oleh karena itu perlu pengawasan pada setiap produk barang dan / atau jasa UMKM oleh Dinas Perindustrian dan Perdagangan untuk memberi perlindungan pada konsumen dan UMKM mampu bersaing di pasar internasional.

Produk UMKM ada dua jenis yaitu barang dan /atau jasa. Guna menghindari meluasnya permasalahan yang akan dibahas perlu diadakan pembatasan masalah. Fokus pembahasan masalah dalam makalah ini adalah pada produk UMKM yang berupa barang.

\section{PERUMUSAN MASALAH}

Dalam pendahuluan tertuang uraian latar belakang masalah. Latar belakang masalah menggambarkan dan menjelaskan alasan-alasan perlunya pemgawasan terhadap produk UMKM. Berdasarkan alasan-alasan tersebut diatas maka dapatdirumuskan perumusan masalah sebagai berikut : Bagaimanakah pengawasan terhadap produk UMKM sebagai upaya perlindungan pada konsumen?

\section{PEMBAHASAN}

Pengawasan Terhadap Produk UMKM Sebagai Upaya Perlindungan Pada Konsumen.

\section{Pengertian pengawasan}

Pelaksanaan suatu rencana atau program tanpa diiringi dengan pengawasan yang baik dan berkesinambungan, jelas akan mengakibatkan lambannya tau bahkan tidak tercapainya sasaran dan tujuan yang telah ditentukan.

Beberapa pengertian pengawasan menurut para ahli: $:^{2}$

1. Duncan, mendefinisikan pengawasan sebagai berikut:' tindakan yang menentukan apakah rencana tercapai atau tidak. Secara sederhana pengawas an adalah kegiatan yang dilaksanakan denganmulus tanpa penyimpangan, agar tujuan operasional tercapai dengan mulus tanpa penyimpanganpenyimpangan yang berarti.

2. Mnurut Harold Koontz, bahwa pengawasan adalah pengukuran dan perbaikan terhadap pelaksanaan kaerja bawahan, agar rencana-rencana yang telah dibuat untuk mencapai tujuantujuan perusahaan dapat terselenggara.

3. Menurut Henri Fayol, pengawasan mencakup upaya memeriksa apakah semua terjadi sesuai dengan rencana yang ditetapkan, perintah yang dikeluarkan, dan prinsip yang dianut. Juga dimaksudkan untuk mengetahui kelemahan dan kesalahan agar dapat dihindari kejadiannya dikemudian hari

4. Menurut Maman Ukas, pengawasan adalah suatu proses kegiatan yang dilakukan untuk memantau, mengukur,

2 Riska Suariesti, 2014, Pengaruh Pengawasan Dinas, Terhadap Motivasi Kerja Pegawai Di Dinas Tenaga Kerja Dan Transmigrasi Kabupaten Cirebon, Universitas Pendidikan Indonesia/repositor.upi.edu/perpustakaan.upi.e du, hlm 12-13, diakses tanggal 25 Agustus 2017. 
dan bila perlu melakukan perbaikan atas pelaksanaan pekerjaan sehingga apa yang telah direncanakan dapat dilaksanakan sesuai dengan tujuan yang diinginkan.

5. Menurut Terry, pengawasan adalah semua aktivitas yang dilaksanakan oleh pihak manajer dalam upaya memastikan bahwa hasil sesuai dengan hasil yang direncanakan.

Dari pengertian pengawasan menurut para ahli tersebut di atas, pengertian pengawasan adalah suatu kegiatan yang dilaksanakan untuk memantau, mengukur, dan bila perlu melakukan perbaikan yang dilakukan manajer guna memastikan hasil sesuai dengan yang direncanakan dan tidak terjadi penyimpangan-penyimpangan.

\section{Tujuan Pengawasan}

Pengawasan perlu dilaksanakan guna mencapai tujuan yang sesuai dengan yang direncanakan. Maka ada beberapa tujuan pengawasan yang berguna bagi pihak-pihak yang melaksanakan kegiatan pengawasan seperti yang dilakukan Soekarno. Tujuan pengawasan adalah: ${ }^{3}$

1. Untuk mengetahui apakah suatu kegiatan sesuai dengan intruksi.

2. Untuk mengetahui apakah suatu kegiatan sudah berjalan sesuai dengan rencana.

3. Untuk mengetahui apakah kegiatan telah berjalan efisien.

4. Untuk mengetahui kesulitan-kesulitan dan kelemahan-kelemahan atau kegagalan ke arah perbaikan.

Adapun tujuan pengawasan menurut Soewarno Handayaningrat:

1. Tujuan untuk mencegah atau memperbaiki kesalahan, penyimpang an, ketidaksesuaian, penyelewengan dan lainnya yang tidak sesuai dengan tugas dan wewenang yang telah ditentukan.

3 Riska Suerasti, Idem. Hlm. 14
2. Bertujuan agar pelaksanaan pekerjaan diperoleh secara berdaya guna dan berhasil guna sesuai dengan rencana yang telah ditentukan sebelumnya.

Jadi tujuan pengawasan adalah untuk mengetahui apakah suatu kegiatan sudah sesuai dengan instruksi, berjalan sesuai dengan rencana sehingga berjalan efisien, berhasil guna dan berdaya guna tidak terjadi kesalahan, penyimpangan, ketidaksesuaian, penyelewengan dan lainnya yang tidak sesuai dengan tugas dan wewenang yang telah ditentukan.

\section{Pengendalian dan Pengawasan Mutu Produk oleh Dinas Perindustrian dan Perdagangan.}

Pengendalian dan pengawasan atas mutu produk beredar di pasaran meliputi Standar Nasional Indonesia (SNI) wajib, Label dan Barang yang diatur tata niaganya, meliputi: ${ }^{4}$

- Pengawasan Barang Beredar di pasaran (SNI Wajib dan MKG).

- Pengawasan Label pada kemasan.

- Pengawasan Barang yang diatur tata niaganya.

Adapun maksud diadakannya pengawasan adalah:

a. Melakukan pengawasan terhadap peredaran barang/produk/jasa yang beredar di pasar.

b. Melakukan bimbingan dan pembinaan pada pelaku usaha yang memproduksi maupun menjual agar mempedomani dan melaksanakan usahanya sesuai dengan aturan dan ketentua yang berlaku.

adalah :

Sedangkan tujuan dari pengawasan

a. Semakin berkurangnya barang-barang dan/atau jasayang beredar di pasaran yang tidak sesuai dengan ketentuan dan

4 www.sumbarprov.go.id. Program dan Kegiatan Bidang Pengendalian dan Pengawasan Mutu Produk Dinas Perindutrian dan Perdagangan Propinsi Sumatera Barat, diakses tanggal 27 Agustus 2017. 
aturan yang berlaku.

b. Konsumen terlindungi dari kemungkinan resiko gangguan kesehatan, keamanan, dan keselamatan dalam mengkonsumsi barang dan/atau jasa yang beredar.

c. Meningkatnya daya saing dan iklim usaha yang kondusif. adalah:

Sedangkan esensi Pengawasan

a. Menjamin terpenuhinya hak-hak konsumen untuk mengkonsumsi barang dan/atau jasa yang memenuhi aspek Keselamatan, Keamanan, Kesehatan Konsumen dan Lingkungan Hidup (K3L) dan sesuai dengan yang dijanjikan.

b. Mendorong pelaku usaha untuk berusaha dengan jujur dan bertanggung jawab.

c. Meningkatkan daya saing industri dalam negeri.

Ruang lingkup pengawasan meliputi:

a. Barang dan/atau jasa yang beredar di pasar: Standar, label, klausula baku, pelayanan purna jual, cara menjual dan pengiklanan.

b. Barang dan/atau jasa yang dilarang beredar di pasar : Hanya dapat didistribusikan sesuai dengan ketentuan peraturan perundang-undangan.

c. Barang dan/atau jasa yang diatur tata niaganya: Wajib memenuhi ketentuan peraturan perundang-undangan yang berlaku.

d. Perdagangan barang-barang dalam pengawasan : Wajib memenuhi ketentuan peraturan perundangundangan yang belaku.

e. Distribusi : Wajib memenuhi peraturan perundang-undangan yang berlaku.

\section{Usaha Mikro Kecil dan Menengah (UMKM)}

\section{Pengertian UMK}

Pengertian UMKM dapat dilihat dalam Undang-undang Nomor 20 Tahun 2008 tentang Usaha Mikro, Kecil, dan Menengah. Pengertian tersebut dapat di lihat pada Bab I ketentuan Umum. Pemgertiam UMKM dapat dijumpai dalam pasal 1 angka (1), pasal 1 angka (2), dan pasal 1 angka (3), yang berbunyi sebagai berikut:

1. Usaha mikro adalah usaha produktif milik perorangan dan/atau badan usaha perorangan yang memenuhi kriteria saha mikro sebagaimana diatur dalam undang-undang.

2. Usaha kecil adalah usaha ekonomi produktif yang berdiri sendiri, yang dilakukan oleh perorangan atau badan usaha yang bukan merupakan anak perusahaan atau bukan cabang perusahaan yang dimiliki, dikuasai, atau menjadi bagian baik langsung maupun tidak langsung dari usaha menengah atau usaha besar yang memenuhi kriteria usaha kecil sebagaimana dimaksud dalam undang-undang ini.

3. Usaha menengah adalah usaha ekonomi produktif yang berdiri sendiri, yang dilakukan oleh orang perorangan atau badan usaha yang bukan merupakan anak perusahaan atau bukan cabang perusahaan yang dimiliki, dikuasai, atau menjadi bagian baik langsung maupun tidak langsung dengan usahakecil atau usaha besar dengan jumlah kekayaan bersih, atau hasil penjualan tahunan sebagaimana diatur dalam undangundang.

\section{Prinsip dan tujuan pemberdayaan UMKM}

Prinsip-prinsip pemberdayaan UMKM diatur dalam pasal 4 yang berbunyi sebagai berikut:

a. Penumbuhan, kemandirian, kebersama an, dan kewirausahaan usaha mikro, kecil dan menengah untuk berkarya dengan prakara sendiri.

b. Perwujudan kebijakan pubik yang 
transparan, akuntabel, dan berkeadilan.

c. Pengembangan usaha berbasis potensi daerah dan berorientasi pasar sesuai dengan kompetensi usaha mikro, kecil dan menengah.

d. Peningkatan daya saing usaha mikro, kecil dan menengah.

e. Penyelenggaraan perencanaa, pelaksana an, dan pengendalian secara terpadu.

Adapun tujuan pemberdayaan UMKM menurut pasal 5 adalah:

a. Mewujudkan struktur perekonomian nasional yang seimbang, berkembang dan berkeadilan.

b. Menumbuhkan dan mengembangkan kemampuan usaha mikro, kecil dan menengah menjadi usaha yang tangguh dan mandiri.

c. Meningkatkan peran usaha mikro, kecil dan menengah dalam pembangunan daerah, penciptaan lapangan kerja, pemerataan pendapatan, pertumbuhan ekonomi, dan pengentasan rakyat dari kemiskinan.

\section{Kriteria UMKM}

Kriteria UMKM diatur dalam pasal 6 ayat (1) samapai dengan (3) yang berbunyi sebagai berikut:

\section{Kriteria usaha mikro}

Kriteria usaha mikro adalah sebagai berikut:

a. Memiliki kekayaan bersih paling banyak Rp. 50.000.000,00 (lima puluh juta rupiah) tidak termasuk tanah dan bangunan tempat usaha; atau

b. Memiliki hasil penjualan tahunan paling banyak Rp. 300.000.000,00 (tiga ratus juta rupiah).

Dikatakan sebuah usaha itu mikro bilamana memenuhi salah satu kriteia tersebut di atas.

\section{Kriteria usaha kecil}

a. Memiliki kekeyaan bersih lebih dari Rp. 50.000.000,00 (lima puluh juta rupiah) sampai dengan paling banyak $\mathrm{Rp}$. 500.000.000,00 (lima ratus juta rupiah) tidak termasuk tanah dan bangunan tempat usaha; atau

b. Memiliki hasil penjualan tahunan lebih dari Rp. 300.000.000,00 (tiga ratus juta rupiah) sampai dengan paling banyak Rp. 2.500.000.000,00 (dua milyar lima ratu juta rupiah).

Sebuah usaha dikatakan usaha kecil apabila telah memenuhi salah satu kriteria yang terebut di atas.

\section{Kriteria usaha menengah}

a. Memiliki kekayaan bersih lebih dari Rp. 500.000.000,00 (lima ratus juta rupiah) sampai dengan paling banyak $\mathrm{Rp}$. 10.000.000.000,00 (sepuluh milyar rupiah) tidak termasuk tanah dan bangunan tempat usaha; atau

b. Memiliki hasil penjualan tahunan lebih dari Rp. 2.500.000.000,00 (dua milyar lima ratus juta rupiah) sampai dengan paling banyak Rp. 50. 000.000.000,00 (lima puluh milyar rupiah).

Menurut ketentuan undang-undang sebuah usaha termasuk usaha menengah apabila memenuhi salah satu kriteria yang ada dalam undang-undang.

Kriteria-kriteria UMKM tersebut tidak bersifat rigid. Artinya kriteria tersebut dapat berubah. Kriteria dapat berubah sesuai dengan perkembangan per ekonomian.

\section{Perlindungan Bagi Konsumen}

\section{a. Pengertian konsumen}

Pengertian konsumen menurut Pasal 1 butir 15 Undang-undang Nomor 5 Tahun 1999 tentang Larangan Praktik Monopoli dan Persaingan Usaha Tidak 
sehat, adalah sebagai berikut:

Konsumen adalahsetiap pemakai dan atau pengguna barang atau jasa baik untuk kepentingan diri sendiri maupun untuk kepentingan pihak lain.

Sedangkan di dalam Pasal 1 butir 2 Undang-undang Nomor 8 tahun 1999 tentang Perlindungan Konsumen (UUPK) mendefinisikan pengertian konsumen yaitu:

"setiap orang pemakai barang dan/atau jasa yang tersedia dalam masyarakat, baik bagi kepentingan diri sendiri, keluarga, orang lain, maupun mahkluk hidup lain dan tidak untuk diperdagangkan."

Dari pengertian tersebut bahwa konsumen menurut Undang-undang Nomor 5 Tahun 1999 tentang Larangan Praktik Monopoli dan Persaingan Usaha tidak sehat berbeda dengan pengertian konsumen menurut Undang-undang Nomor 8 Tahun 1999 tentang Perlindungan Konsumen. Pengertian konsumen menurut UUPK lebih luas dibandingkan UU Antimonopoli. Dapat disimpukan konsumen adalah end user (pengguna terakhir), tanpa si konsumen merupakan pembeli dari barang dan/atau jasa tersebut.

\section{Hak dan kewajiban konsumen}

\section{a. Hak-hak konsumen}

Pasal 4 UU Perlindungan Konsumen mengatur mengenai hak-hak konsumen antara lain sebagai berikut:

- Hak atas kenyamanan, keamanan, dan keselamatan dalam mengonsumsi barang dan atau jasa;

- Hak untuk memilih barang dan atau jasa serta mendapatkan barang dan atau jasa tersebut sesuai dengan nilai tukar dan kondisi serta jaminan yang dijanjikan;

- Hak atas informasi yang benar, jelas, dan jujur mengenai kondisi dan jaminan barang dan atau jasa;

- Hak untuk didengar pendapat dan keluhannya atas barang dan atau jasa yang digunakan;

- Hak untuk mendapatkan advokasi, perlindungan, dan upaya penyelesaian sengketa perlindungan konsumen secara patut;

- Hak untuk mendapat pembinaan dan pendidikan konsumen;

- Hak untuk diperlakukan atau dilayani secara benar dan jujur serta tidak diskriminatif;

- Hak untuk mendapat kompensasi, ganti rugi dan atau penggantian, apabila barang dan atau jasa yang diterima tidak sesuai dengan perjanjian atau tidak sebagaimana mestinya.

\section{b. Kewajiban konsumen.}

Pasal 5 UUPK menyatakan kewajiban konsumen adalah:

- Membaca dan mengikuti petunjuk informasi dan prosedur pemakaian atau pemanfaatan barang dan atau jasa, demi keamanan dan keselamatan;

- Beritikad baik dalam melakukan transaksi pembelian barang dan atau jasa;

- Membayar sesuai dengan nilai tukar yang disepakati;

- Mengikuti upaya penyelesaian hukum sengketa perlindungan konsumen.

Pengawasan terhadap barang hasil produksi UMKM perlu dilakukan dengan tujuan untuk memberi perlindungan pada konsumen dari perbuatan curang yang dilakukan oleh produsen. Wujud dari perlindungan ini antara lain berupa pengawasan terhadap standar mutu, pelabelan, klusula baku dan pengiklanan. Hal ini sesuai dengan hak-hak konsumen yang diatur dalam Pasal 4 Undang-undang Perlindungan Konsumen yaitu hak atas kenyamanan, keamanan, dan keselamatan dalam mengonsumsi barang dan atau jasa; hak atas informasi yang benar, jelas, dan jujur mengenai kondisi dan jaminan barang dan atau jasa. 


\section{Kesimpulan}

Dalam menghadapi persaingan pasar global pengawasan terhadap hasil produk UMKM sangat diperlukan. Pengawasan meliputi standar mutu, pelabelan, klausula baku, pengiklanan. Pengawasan tersebut penting guna melindungi konsumen dari kerugian barang yang tidak memenuhi standar yang telah ditentukan lembaga yang berwenang.

\section{Saran}

Perlu adanya sosiaslisasi dan penyuluhandari lembaga terkait dalam hal ini DinasPerindustrian dan perdagangan. Sosialisasi dan penyuluhan penting diberikan kepada masyarakat. Mengingat masyarakat sebagai konsumen agar terlindungi hak-haknya sebagai konsumen.

\section{DAFTAR PUTAKA}

Abdul Halim Barkatullah dan Teguh Prasetyo,2006, Bisnis E-commerce Studi Sistem Keamanan dan Hukum Di Indonesia, Pustaka Pelajar, Yogyakarta.

Husni Syawali dan Neni Sri Imaniyati, 2000, Hukum Perlindungan Konsumen, Mandar Maju, Bandung.

H.R Daeng Naja, 2009, Pengantar Hukum Bisnis Indonesia, Penerbit Pustaka Yustisia, Yogyakarta.

Riska Suariesti, 2014, Pengaruh Pengawasan Dinas, Terhadap Motivasi Kerja Pegawai Di Dinas Tenaga Kerja Dan Transmigrasi Kabupaten Cirebon, Universitas Pendidikan Indonesia, Cirebon.

\section{Daftar Perundang-undangan}

Undang-undang Nomor 5 Tahun 1999 tentang Larangan Praktik Monopoli dan Persaingan Usaha Tidak Sehat.

Undang-undang Nomor 8 Tahun 1999 tentang Perlindungan Konsumen.

Undang-undang Nomor 20 Tahun 2008 tentang Usaha Mikro, Kecil, dan Menenengah. 